Article

\title{
A Thermocycler Using a Chip Resistor Heater and a Glass Microchip for a Portable and Rapid Microchip-Based PCR Device
}

\author{
Dongsun Yeom ${ }^{1} \mathbb{D}$, Jeongtae $\mathrm{Kim}^{1}{ }^{1}$, Sungil Kim ${ }^{2} \mathbb{D}$, Sanghoon Ahn ${ }^{2} \mathbb{D}$, Jiyeon Choi ${ }^{2} \mathbb{D}$, Youngwook Kim $^{3}$ \\ and Chiwan Koo ${ }^{1, *(D)}$
}

check for

updates

Citation: Yeom, D.; Kim, J.; Kim, S.; Ahn, S.; Choi, J.; Kim, Y.; Koo, C. A Thermocycler Using a Chip Resistor Heater and a Glass Microchip for a Portable and Rapid Microchip-Based PCR Device. Micromachines 2022, 13, 339. https://doi.org/10.3390/ mi13020339

Academic Editors: Han Zhang, Wen Zhang, Nebras Sobahi, Renny Edwin Fernandez and Jing Dai

Received: 17 January 2022

Accepted: 19 February 2022

Published: 21 February 2022

Publisher's Note: MDPI stays neutral with regard to jurisdictional claims in published maps and institutional affiliations.

Copyright: (C) 2022 by the authors. Licensee MDPI, Basel, Switzerland. This article is an open access article distributed under the terms and conditions of the Creative Commons Attribution (CC BY) license (https:// creativecommons.org/licenses/by/ $4.0 /)$.
1 Department of Electronic Engineering, Hanbat National University, Daejeon 34158, Korea; yds1410@naver.com (D.Y.); jeotae@daum.net (J.K.)

2 Department of Laser and Electron Beam Application, Korea Institute of Machinery and Materials, Daejeon 34103, Korea; sung1@kimm.re.kr (S.K.); shahn@kimm.re.kr (S.A.); jchoi@kimm.re.kr (J.C.)

3 Department of Electronic Engineering, Sogang University, Seoul 04107, Korea; youngkim@sogang.ac.kr

* Correspondence: cwankoo@hanbat.ac.kr; Tel.: +82-42-821-1168

Abstract: This study proposes a rapid and inexpensive thermocycler that enables rapid heating of samples using a thin glass chip and a cheap chip resistor to overcome the on-site diagnostic limitations of polymerase chain reaction (PCR). Microchip PCR devices have emerged to miniaturize conventional PCR systems and reduce operation time and cost. In general, PCR microchips require a thin-film heater fabricated through a semiconductor process, which is a complicated process, resulting in high costs. Therefore, this investigation substituted a general chip resistor for a thin-film heater. The proposed thermocycler consists of a compact glass microchip of $12.5 \mathrm{~mm} \times 12.5 \mathrm{~mm} \times 2 \mathrm{~mm}$ that could hold a $2 \mu \mathrm{L}$ PCR sample and a surface-mounted chip resistor of 6432 size $(6.4 \mathrm{~mm} \times 3.2 \mathrm{~mm})$. Improving heat transfer from the chip resistor heater to the PCR reaction chamber in the microchip was accomplished via the design and fabrication of a three-dimensional chip structure using selective laser-induced etching, a rapid prototyping technique that allowed to be embedded. The fabricated PCR microchip was combined with a thermistor temperature sensor, a blower fan, and a microcontroller. The assembled thermocycler could heat the sample at a maximum rate of $28.8^{\circ} \mathrm{C} / \mathrm{s}$ per second. When compared with a commercially available PCR apparatus running the same PCR protocol, the total PCR operating time with a DNA sample was reduced by about $20 \%$.

Keywords: polymerase chain reaction; glass PCR microchip; chip resistor heater; SLE

\section{Introduction}

Polymerase chain reaction (PCR) is an indispensable technology that is used to amplify deoxyribonucleic acid (DNA) in various fields such as molecular biology, medical science, criminal investigations, and disease diagnosis because of its high selectivity and high sensitivity [1-3]. Especially, this technology in the disease diagnosis has the advantage of detecting a very small amount of target (viruses or bacteria) in the body for early diagnosis. Therefore, the literature contains several reports of several point-of-care (POC) PCR devices being used to conduct on-site testing in locations with large floating populations such as airports or ports to prevent the spread of highly infectious diseases [4-8]. In the typical PCR process, the thermal cycle of $94{ }^{\circ} \mathrm{C}-60{ }^{\circ} \mathrm{C}-72{ }^{\circ} \mathrm{C}$ is repeated 30 to 40 times. This process involves the low heating rate of a conventional thermal cycler in heating and cooling tens of microliter volume PCR reaction samples, with a duration of 2 to $3 \mathrm{~h}$, an extended period that poses an obstacle in POC diagnosis $[9,10]$.

Recent advances in microfluidics and micro/nano fabrication technologies led to the development of various miniaturized PCR systems. These systems used a microchip requiring only a few micro- to nano-liter volume samples [11-15]. In addition, various 
heating methods were reported to reduce heating and cooling time in miniaturized PCR systems. In general, microchips were heated by a thin-film metal heater, a thermoelectric module (Peltier element), a cement resistor, or other methods.

When using a metallic thin-film heater that is patterned on the surface of a microchip, the distance between the heater and the reaction chamber in the microchip is small to facilitate the rapid heating of the reaction sample due to excellent heat conduction. Lim et al. presented a platinum $(\mathrm{Pt})$ thin-film on a quartz chip, serving as a heater and a temperature sensor. The PCR microchip, composed of polyethylene terephthalate (PET) and polyimide (PI), was placed between heater chips [16]. Koo et al. reported a microchip fabrication by bonding a heater-patterned glass chip using gold $(\mathrm{Au})$ and a chamber-etched glass microchip, which heated a sample at a maximum rate of $5.5^{\circ} \mathrm{C}$ per second [17]. Veltkamp et al. similarly used $\mathrm{Au}$ as a heater and temperature sensor on a glass PCR chip [18]. These PCR microchips with thin-film metal heaters provide good heating efficiency. However, fabricating these chips can be costly due to the inherent complexity of using microelectronic mechanical Systems (MEMS) processes such as metal deposition, photolithography, and etching. Recently, printed circuit board (PCB)-based heater devices using thin metal lines on a PCB as a heater have been developed. For example, Kaprou et al. reported a PCB-based heater combined with a microfluidic channel to conduct continuous flow and static PCR methods $[19,20]$.

Gou et al. and Sreejith et al. reported PCR systems using a Peltier heater. This technique used a single element to heat and cool and provided high reliability in terms of temperature control. However, the device was expensive to manufacture and exhibited high power consumption compared to other external heaters. In addition, a Peltier heater needs to incorporate a cooling system for effective heating. For this reason, this approach required additional components such as a heatsink and cooling fan, which increased the size of the system [21,22].

Mendoza-Gallegos et al. reported a PCR system using inexpensive cement resistors. However, the non-uniform surface temperature of a cement resistor may lead to an imbalance in the PCR sample temperature [23].

We propose a low-cost, compact commercial surface-mount device (SMD) chip resistorbased heater to overcome these limitations. A chip resistor heater can generate rapid heating by using an overcurrent, and its compact size allows localized heating of the small reaction chamber of the microchip. Moreover, the chip resistor heater device requires no additional fabrication since standard chip resistors are commercially available, and the flat surface allows simple placement on a microchip. We improved heat transfer from the chip resistor heater to the PCR reaction chamber in the proposed microchip by simulating and fabricating a three-dimensional chip structure in which the chip resistor could be embedded. A blower fan and a temperature sensor were combined with the chip resistorbased heater. A microcontroller controlled the temperature of the PCR reaction chamber with proportional-integral-derivative (PID) feedback. A black plastic housing designed to enclose all components was fabricated using a fused deposition modeling (FDM)-type 3D printer. The fabricated chip resistor-based heater was demonstrated by amplifying DNA (ZFP36, Human tagged ORF clone) and conducting gel-electrophoresis.

As a material commonly used in PCR microchips, glass was selected for this device. Polymers and glass are widely used because they are biocompatible and optically transparent. Typically, polydimethylsiloxane (PDMS), polymethyl methacrylate (PMMA), and polycarbonate (PC) are used in low-cost polymer microchips. However, PDMS has gas permeability and difficulty in mass production. PMMA's low glass transition temperature of $105^{\circ} \mathrm{C}$ makes it unsuitable for the PCR denaturation step at high temperatures (about $95^{\circ} \mathrm{C}$ ). PC has a disadvantage in optical detection in real-time microchip PCR systems because of its autofluorescence [24,25]. In contrast, glass has high light transmittance, heat resistance, electrical insulation, and high thermal conductivity compared to polymer [26]. Glass has its own limitations, of course, including the long fabrication time and effort required for micromachining, along with the need for special tools or a clean room facility. 
Using a two-step selective laser-induced etching (SLE) process, these limitations were overcome. The first step of the process involves modifying the target area of the glass chip using the nonlinear absorption of a femtosecond laser. Next, wet etching is used to remove the portion modified by the laser. This process allows the fabrication of a 3D hollow structure inside one single glass without a bonding process, making it useful for rapidly fabricating a prototype glass microchip [27-29]. Earlier, we reported an optimization method for fabricating 3D structures in a single glass sheet using the SLE process $[30,31]$. This study used the optimized SLE process conditions to fabricate a PCR reaction chamber and a chip resistor slot in the glass microchip.

\section{Materials and Methods}

A PCR microchip with a chip resistor heater was designed, and finite element method (FEM) software was used to simulate the temperature profile of the microchip when heated by the chip resistor heater. As shown in Figure 1, a circular PCR reaction chamber was placed inside a glass substrate, and the heater was placed above the chamber. The dimension of the glass substrate was $12.7 \mathrm{~mm} \times 12.7 \mathrm{~mm} \times 2 \mathrm{~mm}$, small enough to be placed in a portable thermocycler. The diameter of the chamber was $5 \mathrm{~mm}$, and the height was $0.1 \mathrm{~mm}$, in order to hold $2 \mu \mathrm{L}$ of PCR sample to be amplified. The temperature profile around the chamber was simulated while moving the position of the heater. Three distances between the heater and the chamber $(600 \mu \mathrm{m}, 950 \mu \mathrm{m}$, and $1300 \mu \mathrm{m})$ were used for the simulation. The chamber's inlet and outlet were not considered in the simulation.

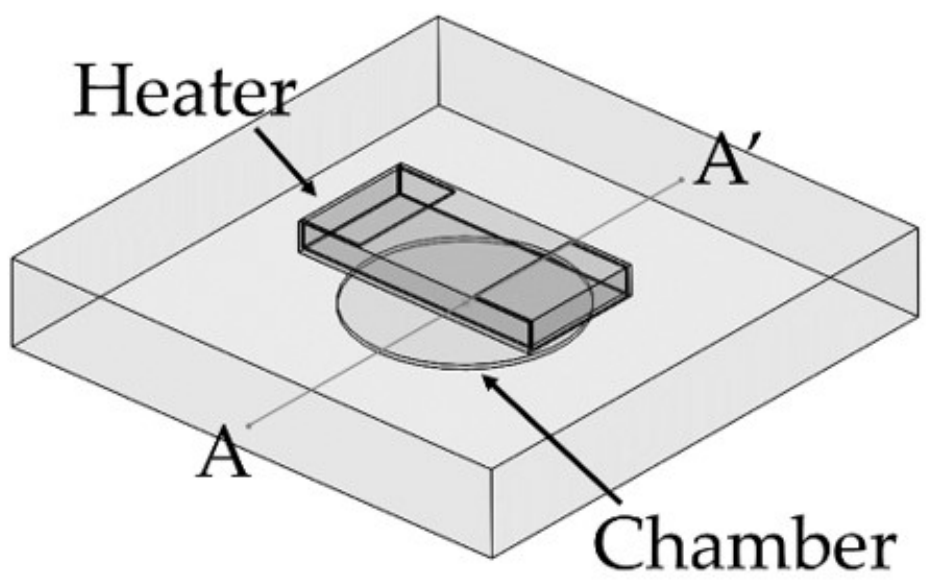

Figure 1. Illustration of the PCR microchip using a chip resistor as a heater. The chamber was located in a glass substrate $(12.5 \mathrm{~mm} \times 12.5 \mathrm{~mm} \times 2 \mathrm{~mm})$, and the diameter and the height of the PCR reaction chamber were $5 \mathrm{~mm}$ and $0.1 \mathrm{~mm}$, respectively.

We fabricated a portable PCR device to amplify DNA samples to demonstrate the proposed combination of a microchip and chip resistor heater. Figure 2 illustrates the PCR device, consisting of a thermocycler, a control circuit, and a microcontroller unit (MCU). The thermocycler comprises a microchip, a chip resistor heater, a blower fan, and a thermistor. The control circuit includes peripheral circuits for switching current, and the MCU controls the PCR thermocycling temperature. In addition, a hole is included at the bottom of the thermocycler to allow the addition of an optical detection component to the thermocycler for expansion into a real-time PCR device. 


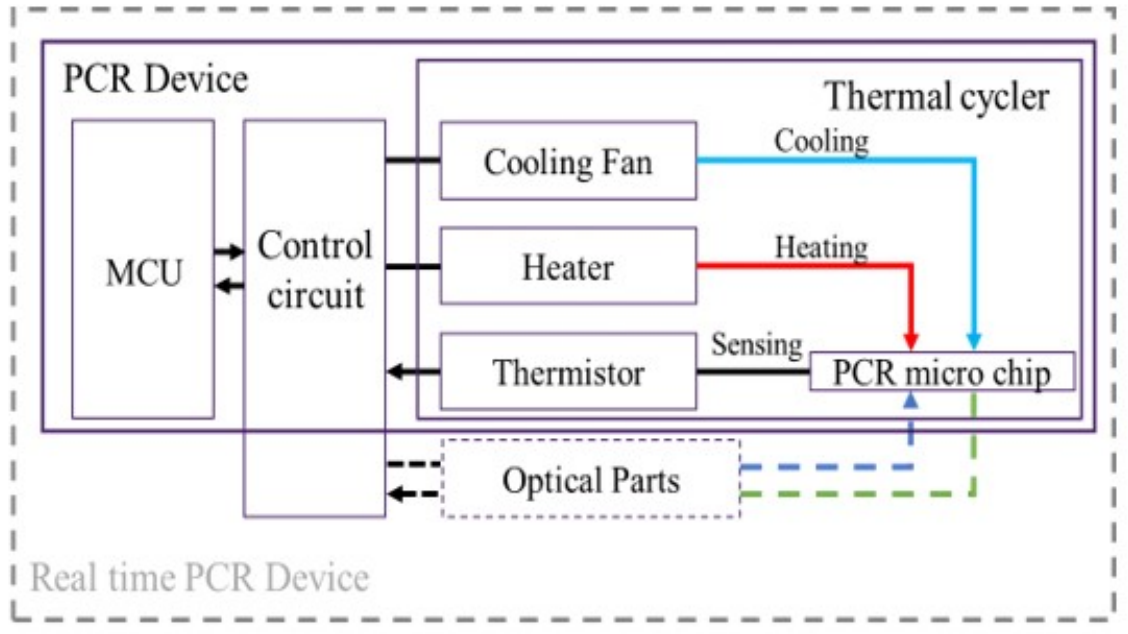

Figure 2. An overview of the PCR device, including a thermal cycler, control circuit, and microcontroller unit (MCU).

As shown in Figure 3, the thermocycler module consisted of a heater module, a microchip, rubber, and a housing with a cover. The heater module included the chip resistor heater and the thermistor for heating the microchip and sensing the temperature of the microchip. A blower fan, used to accelerate the cooling of the microchip, rotated at $3400 \mathrm{rpm}$ and blew the hot air in the thermocycler module to the outside. The microchip's inlet and outlet were sealed with rubber. In addition, a screw structure was manufactured on the cover and the housing. Rotating the cover to close the housing caused the rubber, the microchip, and the heater module to be pressed together with strong pressure, which prevented PCR sample evaporation and improved heat transfer between the chip resistor and the microchip.

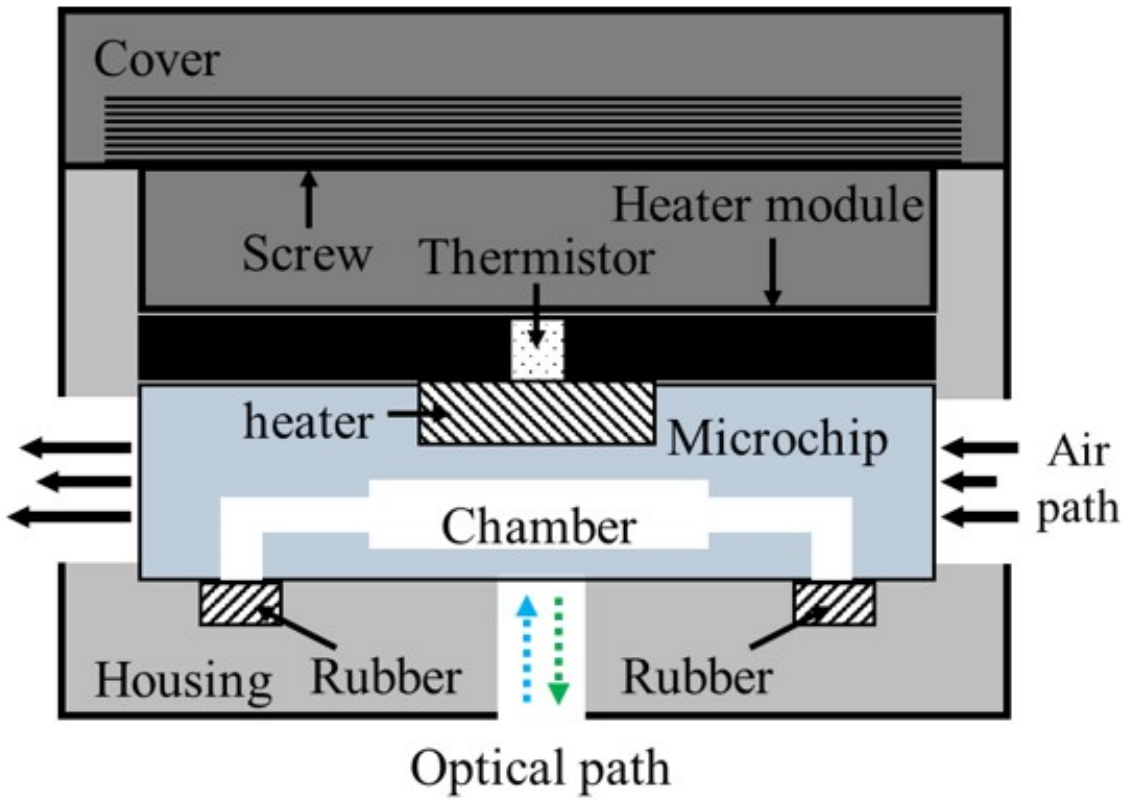

Figure 3. Schematic of the thermocycler module.

The glass PCR microchip was fabricated by the SLE process using a femtosecond laser according to the design determined through the temperature profile simulation. The distance between the chip resistor heater and the PCR reaction chamber was $600 \mu \mathrm{m}$. In addition, a heater slot was designed so that the chip resistor heater could be placed at the exact center of the PCR reaction chamber (Figure 4A). To fabricate cavity structures 
for the PCR chamber and the heater slot in the glass microchip, we performed a two-step process with laser direct writing and etching with the optimized SLE process conditions (Figure 4B) $[30,31]$. This technique allowed the fast and easy fabrication of a 3D cavity inside the glass.

As shown in Figure 4C, a single PCB $(15 \mathrm{~mm} \times 20 \mathrm{~mm} \times 0.7 \mathrm{~mm})$ for the heater module was designed. The chip resistor heater and the thermistor were placed on each side of the PCB to allow the thermistor to directly measure the temperature of the chip resistor heater. A POGO pin was used for a simple electrical connection to the control circuit and easy replacement of the heater module (Figure 4D). The heater module was integrated with the microchip by placing the chip resistor heater into the slot of the microchip.

Rubber septa were used to seal the PCR microchip's inlet and outlet and prevent evaporation during PCR. The housing and the cover were designed to enclose all components of the thermocycler (Figure 4E) and prototyped with an FDM-type 3D printer and black polylactic acid (PLA) filament.

(A)

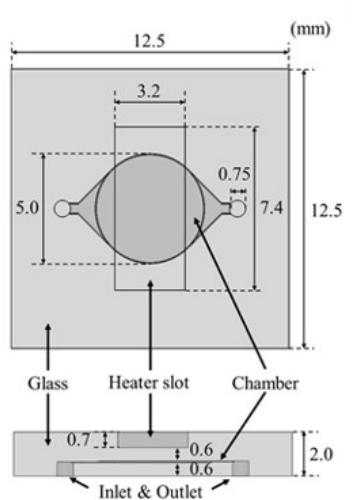

(B)

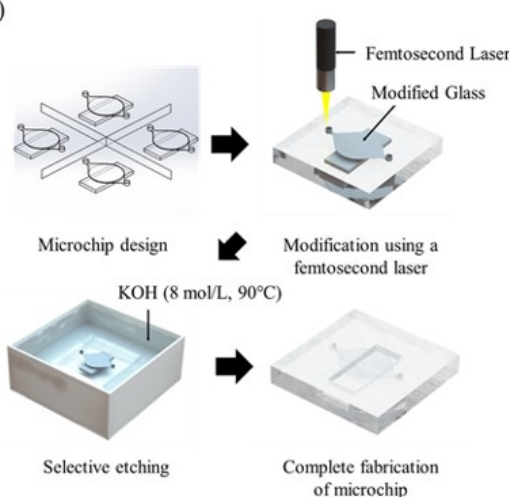

(C)
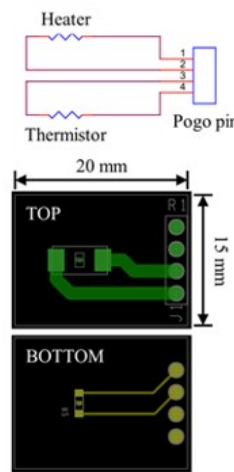

(E)

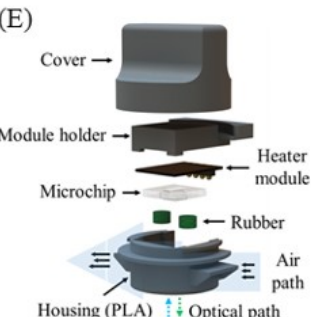

Housing (PLA)

(D)

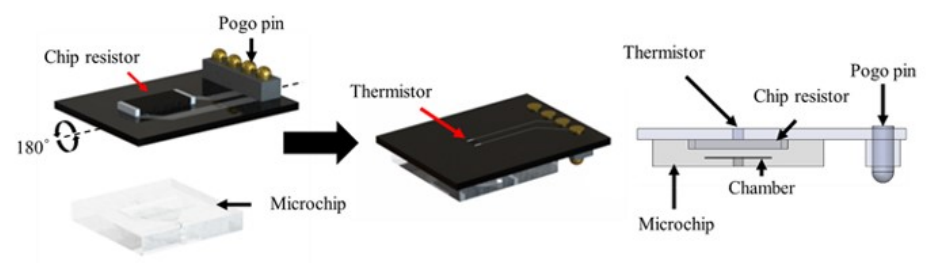

Figure 4. (A) PCR microchip. (B) Microchip fabrication steps using the SLE process. (C) Heater module circuit and PCB design. (D) Schematic of the heater module including a chip resistor heater and a thermistor, and the integrated heater module with the microchip. (E) Components of the thermocycler module.

Next, the thermocycler module was connected to the control circuit composed of two metal-oxide-semiconductor field-effect transistors (MOSFET) and a voltage divider. The MOSFETs switched electrical current to the chip resistor heater and the blower fan, while the voltage divider circuit was used to measure the temperature of the thermistor. The MCU provided thermocycling by simultaneously controlling the MOSFET switches and collecting temperature data. In the MCU, the PID control was processed by calculating the error from the target temperature value by receiving feedback about the current temperature of the sample [32]. An Arduino was used as the MCU to connect with many peripheral devices.

To verify the DNA amplification of our PCR device, we employed a commercial PCR device (PCR Thermal Cycler Dice ${ }^{\circledR}$ Gradient, TaKaRaBio, Japan, Heating rate: $3.0^{\circ} \mathrm{C} / \mathrm{s}$, Cooling rate: $2.0^{\circ} \mathrm{C} / \mathrm{s}$ ). The templated DNA of Human Tagged ORF Clone (ZFP36, ORIGENE, Rockville, MD, USA) was used to compare our PCR device with the commercial PCR device. The primer gene consisted of a forward primer ( $5^{\prime}$ ATT AGG ACA AGG CTG GG $3^{\prime}$ ) and a reverse primer (5' GGA CTT AAA ATG TCG 3') to produce a $978 \mathrm{bp}$ amplicon. 
Bovine serum albumin (BSA) was dissolved in phosphate-buffered saline (PBS) at a ratio of $2 \mu \mathrm{g} / \mu \mathrm{L}$ to prepare a BSA solution for preventing DNA adsorption on the surface of the reaction chamber in the PCR microchip. The BSA solution was loaded into the reaction chamber for $60 \mathrm{~min}$ at room temperature. Then, the chamber was rinsed with PBS and a PCR mix sample was loaded into the reaction chamber. The composition ratio of the PCR sample is listed in Table 1. PCR was carried out under the following conditions: $30 \mathrm{~s}$ at $95{ }^{\circ} \mathrm{C}$ (pre-denaturation), followed by 30 cycles of $95^{\circ} \mathrm{C}$ for $30 \mathrm{~s}$ (denaturation), $30 \mathrm{~s}$ at $60{ }^{\circ} \mathrm{C}$ (annealing), and $30 \mathrm{~s}$ at $72{ }^{\circ} \mathrm{C}$ (extension).

Table 1. Composition ratio of sample for PCR.

\begin{tabular}{cccc}
\hline Step & Name & Volume $(\mathbf{2 . 0} \mu \mathrm{L})$ & Remarks \\
\hline 1 & Deionized Water & $1.2 \mu \mathrm{L}$ & \\
2 & DNA template & $0.1 \mu \mathrm{L}$ & TTP $(80 \mu \mathrm{L} / \mathrm{mL})$ \\
3 & Forward Primer & $0.1 \mu \mathrm{L}$ & $10 \mathrm{pmol} / \mu \mathrm{L}($ XL39) \\
4 & Reverse Primer & $0.1 \mu \mathrm{L}$ & $10 \mathrm{pmol} / \mu(\mathrm{VP} 1.5)$ \\
5 & $5 \times$ reaction Buffer & $0.4 \mu \mathrm{L}$ & $5 \times$ reaction Mix \\
6 & Enzyme & $0.1 \mu \mathrm{L}$ & Premium-Pfu \\
\hline
\end{tabular}

\section{Results \& Discussion}

The temperature distribution over the entire PCR microchip was obtained via FEM simulation. As shown in Figure 5, heat transfer from the heater was analyzed in three instances: for a distance between the chip resistor heater and the reaction chamber $(\mathrm{H})$ of $600 \mu \mathrm{m}\left(\mathrm{H}=\mathrm{H}_{1}=600 \mu \mathrm{m}\right)$, when the heater was inserted half into the microchip $\left(\mathrm{H}=\mathrm{H}_{2}=950 \mu \mathrm{m}\right)$, and when the heater was placed on the microchip $\left(\mathrm{H}=\mathrm{H}_{3}=1300 \mu \mathrm{m}\right)$. Figure $5 \mathrm{~B}$ shows the temperature distribution on the microchip when the temperature of the sample in the chamber was heated to $94^{\circ} \mathrm{C}$. Additionally, a distance-temperature graph was obtained from the temperature data for line A- $\mathrm{A}^{\prime}$ of Figure 1 that passed through the chamber's center, showing a temperature variation within $2.3^{\circ} \mathrm{C}, 2.6^{\circ} \mathrm{C}$, and $3.2^{\circ} \mathrm{C}$ when the distance $\mathrm{H}$ was $\mathrm{H}_{1}, \mathrm{H}_{2}$, and $\mathrm{H}_{3}$, respectively.

(B)
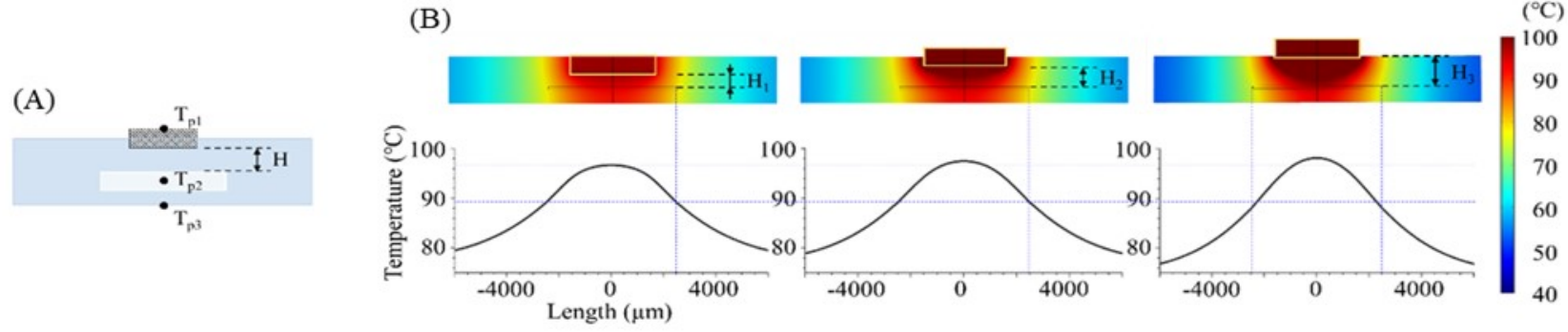

Figure 5. (A) Cross sectional view of the microchip (across $A-A^{\prime}$ in Figure 1). While changing the distance between the chamber and the heater, the temperature on three points was calculated using FEM simulation $\left(\mathrm{T}_{\mathrm{p} 1}\right.$ : heater, $\mathrm{T}_{\mathrm{p} 2}$ : PCR sample, $\mathrm{T}_{\mathrm{p} 3}$ : microchip surface). (B) Simulated temperature profile of the microchip when $\mathrm{H}_{1}, \mathrm{H}_{2}$, and $\mathrm{H}_{3}$ were 600 , 950, and $1300 \mu \mathrm{m}$, respectively.

Table 2 displays the heating time when the sample temperature $\left(\mathrm{T}_{\mathrm{p} 2}\right)$ reached $94{ }^{\circ} \mathrm{C}$, along with the $\mathrm{T}_{\mathrm{p} 1}$ and $\mathrm{T}_{\mathrm{p} 3}$ temperatures at that time. As the distance between the heater and the chamber decreased, less time was needed for $\mathrm{T}_{\mathrm{p} 2}$ to be heated to the target temperature, resulting in an increasingly uniform sample temperature. For a distance $\mathrm{H}$ of $600 \mu \mathrm{m}\left(\mathrm{H}_{1}\right)$, the time to reach the target temperature was $3.6 \mathrm{~s}$ and $8.8 \mathrm{~s}$ faster than for the distances represented by $\mathrm{H}_{2}$ and $\mathrm{H}_{3}$, respectively. In addition, the temperature uniformity in the chamber was shown with the standard deviation of the temperature at $\mathrm{T}_{\mathrm{p} 2}$, and the microchip with distance $\mathrm{H}(600 \mu \mathrm{m})$ yielded a more uniform temperature than other conditions. The simulation results demonstrated the heater's capability with distance 
$\mathrm{H}=600 \mu \mathrm{m}$ when used for controlling the thermocycling temperature with the temperature sensor and the MCU.

Table 2. Simulation result to time to reach sample temperature of $94{ }^{\circ} \mathrm{C}$ for each condition.

\begin{tabular}{lcccc}
\hline $\begin{array}{l}\text { Distance between } \\
\text { Heater and Chamber }\end{array}$ & $\begin{array}{c}\text { Time to Be Heated to } \\
\mathbf{9 4}{ }^{\circ} \mathbf{C} \text { at } \mathbf{T}_{\mathbf{p} 2}\end{array}$ & $\begin{array}{c}\text { Temperature at Heater } \\
\text { Surface }\left(\mathbf{T}_{\mathbf{p} 1}\right)\end{array}$ & $\begin{array}{c}\text { Temperature of Sample } \\
\text { in Chamber }\left(\mathbf{T}_{\mathbf{p} 2}\right)\end{array}$ & $\begin{array}{c}\text { Temperature of } \\
\text { Surface }\end{array}$ \\
\hline $\left.\mathrm{T}_{\mathbf{p} 3}\right)$
\end{tabular}

A glass microchip with a 3D structure was successfully executed using SLE. The heater slot, sample chamber, inlet, and outlet structures were etched on a single glass sheet as designed.

Next, the fabricated heater module on a PCB was integrated with the microchip, as shown in Figure 6. The entire housing and cover were printed with black PLA filament using an FDM-type 3D printer. However, the printed part around the heater module was deformed after several thermo cycling tests due to its low glass transition temperature of around $60^{\circ} \mathrm{C}$ to $65^{\circ} \mathrm{C}$. Consequently, an additional housing part that served as a thermal blocker was printed using polycarbonate (PC) filament. The resulting glass transition temperature was about $147^{\circ} \mathrm{C}$; therefore, the PC thermal blocker was not deformed while repeating thermal cycling.

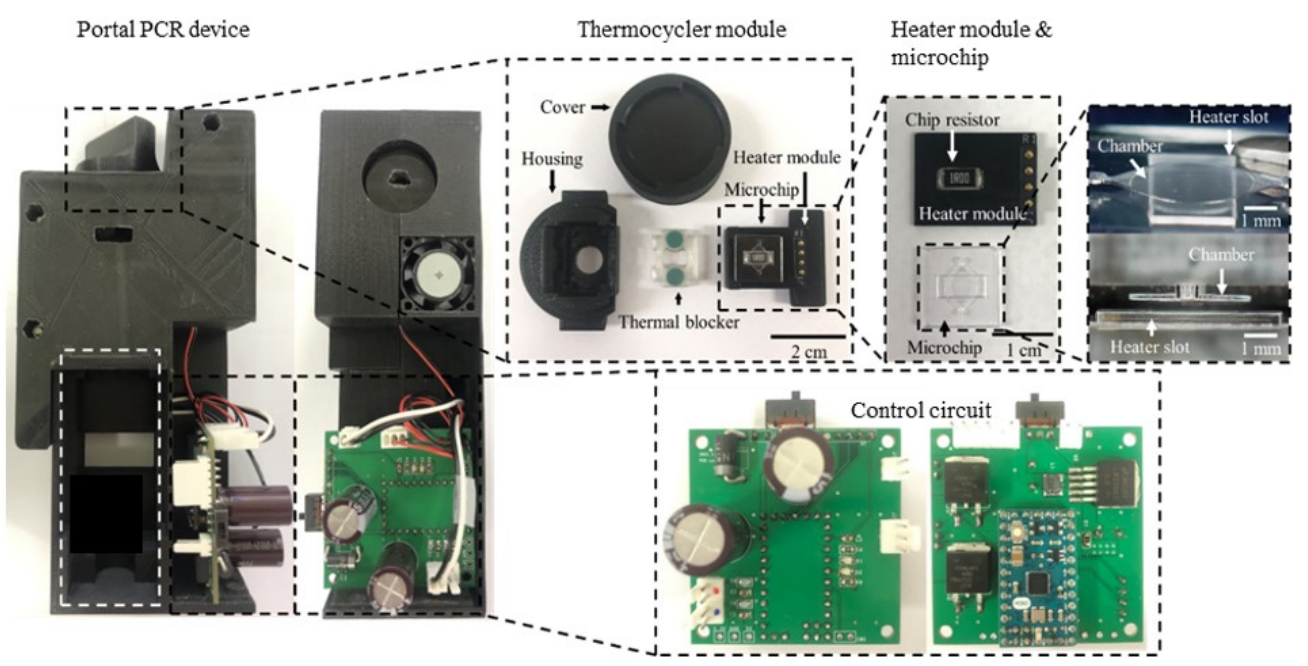

Figure 6. The fabricated PCR device. It consists of the thermocycler module and the control circuit with the MCU. The 3D glass microchip was successfully manufactured by the SLE process. The housing for enclosing all components was fabricated using a 3D printer.

The thermocycling control function was performed by connecting the thermocycler module to the control circuit with the MCU. Using the PID control scheme required obtaining the current temperature of the sample. However, placing a temperature sensor in the sample chamber that can only hold a sample comprising a few micro-liters is a challenging prospect. In addition, while sealing the inlet and the chamber's outlet is difficult, an incomplete seal may result in the evaporation of the sample. Because of the inability to directly measure the current temperature of the sample, the heater's temperature was monitored via its associated thermistor, and the temperature of the sample was calculated based on the simulation result of the relationship between the heater temperature and the sample temperature.

To characterize the performance of the PID temperature control, the temperature distribution of the microchip was simulated and measured (Figure 7). For this measurement, 
a thermal imaging camera was used. While the thermal image does not show the temperature of the sample inside the microchip, it does provide the temperature distribution on the surface of the microchip. Figure 7A illustrates that the heat transferred from the chip resistor heater to the outside of the microchip and the temperature on the surface of the microchip (above the chamber) was maintained at $92{ }^{\circ} \mathrm{C}$. In the thermal image shown in Figure 7B, the microchip's surface temperature distribution was similar to the shape seen in Figure $7 \mathrm{~A}$.

(A)

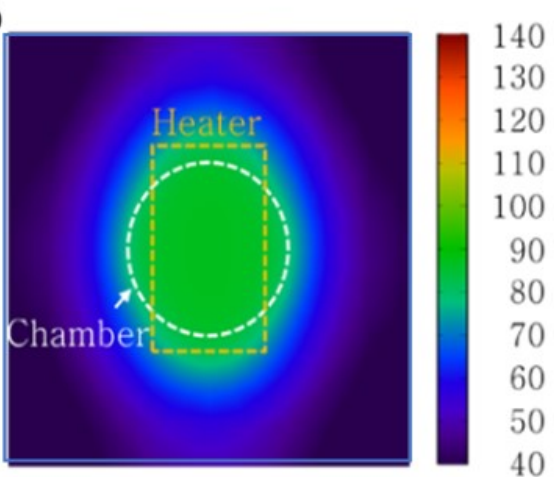

(B)

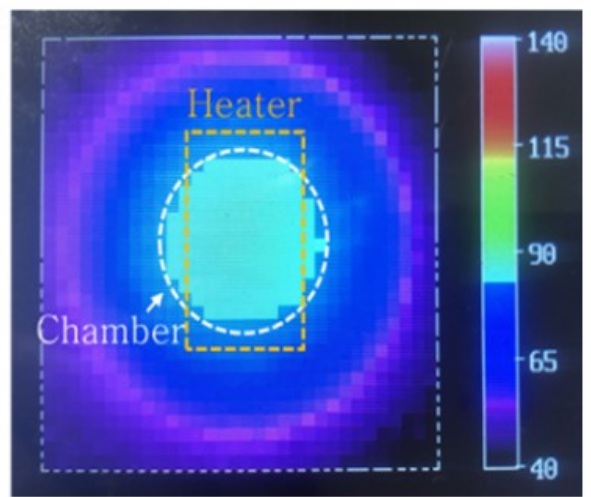

Figure 7. (A) Simulation result visualizing the temperature distribution on the surface of the microchip (B) Thermal image of the microchip surface using a thermal imaging camera. The temperature profile of the sample inside the chamber was uniform.

After characterizing the temperature distribution of the microchip, the PCR thermocycling experiment was conducted. This procedure involved operating 30 cycles with the condition matching the conventional PCR condition shown in Table 3 (a single cycle: $30 \mathrm{~s}$ at denaturation, $30 \mathrm{~s}$ at annealing, and $30 \mathrm{~s}$ at extension, including a $30 \mathrm{~s}$ pre-denaturation step at $95^{\circ} \mathrm{C}$ ). Figure 8 shows the temperature data as a time and temperature graph. The fabricated chip resistor heater was well-controlled to the target temperature, and the thermocycler demonstrated constant performance for 30 cycles. The total PCR thermocycling process consumed $3511 \mathrm{~s}$, which can be broken down to the duration of each part of the procedure as follows: the steps for the 30 cycles comprised $77 \%$ ( $2730 \mathrm{~s}$ ) of the time taken, while the pre-denaturation step took $1 \%$ (30 s) of the time, and $21 \%(751 \mathrm{~s})$ represents the time needed for heating and cooling between each step. The heating rate from the extension step to the denaturation step was $28.8^{\circ} \mathrm{C} / \mathrm{s}$; meanwhile, the heating rate from the annealing step to the extension step was $15.0^{\circ} \mathrm{C} / \mathrm{s}$, and the cooling rate was $1.4^{\circ} \mathrm{C} / \mathrm{s}$. The reason for the faster heating rate from extension to denaturation compared to that from annealing to the extension has not yet been determined. We assume that the air around the microchip during the extension step was hotter than at annealing, potentially affecting the heating rate. Table 4 compares the performance of our thermocycling device with the reported results for other PCR systems and a commercial PCR machine. The heating rate of our device $\left(21.9{ }^{\circ} \mathrm{C} / \mathrm{s}\right)$ was the average value of $28.8^{\circ} \mathrm{C} / \mathrm{s}$ and $15.0^{\circ} \mathrm{C} / \mathrm{s}$. This result was 4 to 8 times faster than those reported in other studies, except for an experiment that used a cement resistor. The rapid heating rate of our device was due to the minimal distance between the chip resistor and the chamber. Our device's distance of $600 \mu \mathrm{m}$ was shorter than the distance reported for other PCR systems. Increasing the distance from $600 \mu \mathrm{m}$ to $1300 \mu \mathrm{m}$ results in a heating rate that is 2.4 times smaller (according to Table 2). However, the cooling rate was similar to other studies. The air-cooling method in our device did not provide a great effect on discharging heat from the microchip inside the thermocycler housing. 
Table 3. Thermocycle conditions and heating/cooling rate.

\begin{tabular}{|c|c|c|c|c|c|}
\hline & $\begin{array}{c}\text { Thermocycle Step } \\
\text { Changing }\end{array}$ & Transition Time & Transition Rate & Thermocycle Step & Step Time \\
\hline Start & (1) $25^{\circ} \mathrm{C} \rightarrow 95^{\circ} \mathrm{C}$ & $3.2 \mathrm{~s}$ & $21.8^{\circ} \mathrm{C} / \mathrm{s}$ & (2) $95^{\circ} \mathrm{C}$ (Pre-Denaturation) & $30.0 \mathrm{~s}$ \\
\hline 30 cycles & $\begin{array}{l}\text { (1) } 72^{\circ} \mathrm{C} \rightarrow 95^{\circ} \mathrm{C} \\
\text { (3) } 95^{\circ} \mathrm{C} \rightarrow 60^{\circ} \mathrm{C} \\
\text { (5) } 60^{\circ} \mathrm{C} \rightarrow 72{ }^{\circ} \mathrm{C}\end{array}$ & $\begin{array}{c}0.8 \mathrm{~s} \\
24.5 \mathrm{~s} \\
0.8 \mathrm{~s}\end{array}$ & $\begin{array}{l}28.8^{\circ} \mathrm{C} / \mathrm{s} \\
-1.4^{\circ} \mathrm{C} / \mathrm{s} \\
15.0^{\circ} \mathrm{C} / \mathrm{s}\end{array}$ & $\begin{array}{l}\text { (2) } 95^{\circ} \mathrm{C} \text { (Denaturation) } \\
\text { (4) } 60^{\circ} \mathrm{C} \text { (Annealing) } \\
\text { (6) } 72^{\circ} \mathrm{C} \text { (Extension) }\end{array}$ & $\begin{array}{l}30.0 \mathrm{~s} \\
30.0 \mathrm{~s} \\
30.0 \mathrm{~s}\end{array}$ \\
\hline Total time & & & $3511 \mathrm{~s}(58.5 \mathrm{~min})$ & & \\
\hline
\end{tabular}

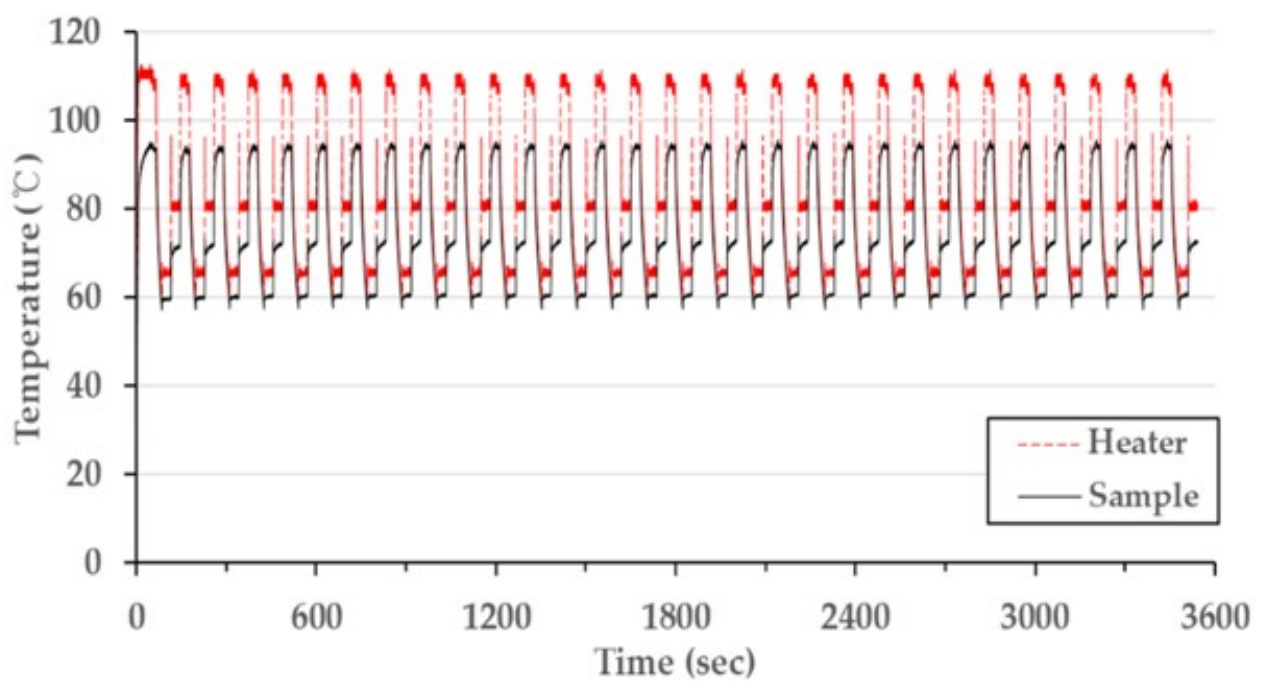

Figure 8. Measured PCR thermocycling profile with PID control.

Table 4. Comparison of thermocycle type, size, and speed.

\begin{tabular}{|c|c|c|c|c|c|c|}
\hline & PCR Type & PCR Chip & Heater Type & $\begin{array}{l}\text { Thermocycler Size } \\
\qquad\left(\mathrm{mm}^{3}\right)\end{array}$ & $\begin{array}{l}\text { Heating Rate } \\
\left({ }^{\circ} \mathrm{C} / \mathrm{s}\right)\end{array}$ & $\begin{array}{c}\text { Cooling Rate } \\
\left({ }^{\circ} \mathrm{C} / \mathrm{s}\right)\end{array}$ \\
\hline Our device & Conventional & Glass & Chip resistor & $40 \times 40 \times 25$ & $\begin{array}{c}21.9 \\
\text { (averaged) }\end{array}$ & 1.4 \\
\hline Wong et al. [8] & Conventional & $\mathrm{N} / \mathrm{A}$ & Thermos & $\mathrm{N} / \mathrm{A}$ & 3.5 & 1.9 \\
\hline Lim et al. [16] & Real-time & Thin film & $\mathrm{Pt}$ & $50 \times 30 \times 20$ & 2.9 & 1.3 \\
\hline Kaprou et al. [20] & Conventional & PMMA & $\mathrm{Cu}(\mathrm{PCB})$ & $\begin{array}{l}\text { depending on the } \\
\text { PCR chip size }\end{array}$ & 1.4 & 0.6 \\
\hline Gou et al. [21] & Digital & PDMS & Peltier & $90 \times 90 \times 50$ & 5.0 & 4.0 \\
\hline M.G. et al. [23] & Real-time & PMMA & Cement resistor & $\mathrm{N} / \mathrm{A}$ & 0.5 & 1.4 \\
\hline Zhu et al. [33] & Conventional & Graphene & Graphene & $\mathrm{N} / \mathrm{A}$ & 4.8 & 9.3 \\
\hline $\begin{array}{c}\text { Commercial PCR } \\
\text { (TaKaRa) }\end{array}$ & Conventional & PCR tube & Peltier & 96 well tube plate & 3.0 & 2.0 \\
\hline
\end{tabular}

Following the thermocycling experiment, we verified the DNA amplification of our PCR device with the templated DNA (ZFP36). After loading the PCR mix into the microchip and a PCR tube using a pipette, we placed the samples in our PCR device and a commercial PCR machine, respectively. The resulting amplicons from the microchip and the PCR tube were extracted and subjected to conventional gel electrophoresis throughout the experiment. The outcome showed strong bands, validating the performance of our PCR device using the microchip with the chip resistor as a heater. Figure 9 illustrates the gel electrophoresis results, including gel bands of amplified DNA, presenting a comparison of the performance of a commercial PCR machine and our PCR device. In addition, the total PCR time of the commercial PCR was about $74 \mathrm{~min}$, while our PCR device took about $59 \mathrm{~min}$ (20\% faster). 


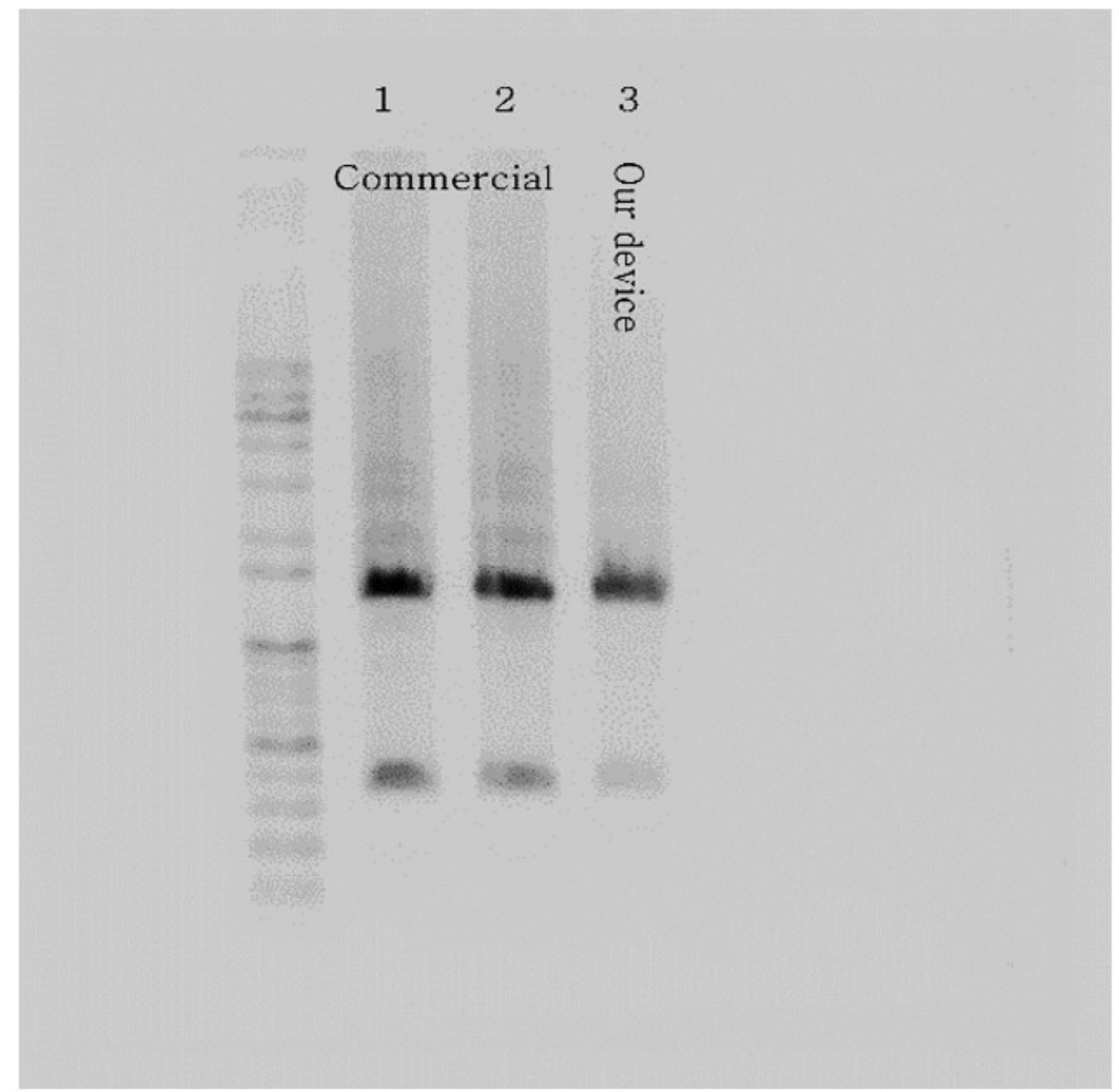

Figure 9. Gel electrophoresis results verify the PCR device with the microchip heated by the chip resistor. The picture shows strong bands of ZFP36 DNA amplified using a commercial PCR machine (samples 1 and 2) and our PCR device (sample 3).

\section{Conclusions}

We proposed a rapid and inexpensive thermocycler that enables rapid heating of samples using a thin glass chip and a cheap chip resistor for a portable microchip-based PCR device. The simulation of the temperature distribution based on the distance between the reaction chamber and the heater suggested that a smaller distance improved the device's heating performance. Fabricating a glass microchip using the SLE simplified the prototyping process into two steps, laser processing and etching, thereby reducing the time needed to fabricate the microchip as designed. A small SMD-type chip resistor heater and a thermistor were soldered onto a single PCB (heater module), which was then placed on the microchip. The slot on the microchip for the placement of the chip resistor allowed the easy assembly of the heater module. A PCR device was fabricated by combining a blower fan for cooling, a switching circuit with an MCU (control circuit) to control the heater module, and the thermocycler, which included the heater module. This device demonstrated rapid heating performance with an average heating rate of $21.9^{\circ} \mathrm{C} / \mathrm{s}$ by locally heating only the chamber area instead of the entire microchip. The proposed formation successfully demonstrated a well-controlled thermocycle and DNA amplification. Moreover, the proposed device's total PCR time for 30 thermocycles was $20 \%$ faster than using a commercial PCR machine. Therefore, the thermocycle technique using a chip resistor can be integrated with a rapid and portable PCR or real-time PCR device for on-site testing. 


\begin{abstract}
Author Contributions: Conceptualization, D.Y. and C.K.; methodology, D.Y. and C.K.; software, J.K and Y.K.; validation, S.K. and S.A.; formal analysis, D.Y. and J.K.; investigation, D.Y., J.K., S.K. and S.A.; resources, J.C., Y.K. and C.K.; data curation, D.Y.; writing-original draft preparation, D.Y. and J.K.; writing-review and editing, J.C., Y.K. and C.K.; visualization, D.Y.; supervision, C.K.; project administration, C.K.; funding acquisition, C.K. All authors have read and agreed to the published version of the manuscript.
\end{abstract}

Funding: This research was supported by the research fund of Hanbat National University in 2017.

Institutional Review Board Statement: Not applicable.

Informed Consent Statement: Not applicable.

Data Availability Statement: Not applicable.

Conflicts of Interest: The authors declare no conflict of interest. The funders had no role in the design of the study; in the collection, analyses, or interpretation of data; in the writing of the manuscript, or in the decision to publish the results.

\title{
References
}

1. Kralik, P.; Ricchi, M. A basic guide to real time PCR in microbial diagnostics: Definitions, parameters, and everything. Front Microbiol. 2017, 8, 108. [CrossRef] [PubMed]

2. Liu, P.; Seo, T.S.; Beyor, N.; Shin, K.J.; Scherer, J.R.; Mathies, R.A. Integrated portable polymerase chain reaction-capillary electrophoresis microsystem for rapid forensic short tandem repeat typing. Anal. Chem. 2007, 79, 1881-1889. [CrossRef] [PubMed]

3. Lin, M.H.; Tseng, C.H.; Tseng, C.C.; Huang, C.H.; Chong, C.K.; Tseng, C.P. Real-time PCR for rapid genotyping of angiotensinconverting enzyme insertion/deletion polymorphism. Clin. Biochem. 2001, 34, 661-666. [CrossRef]

4. Zhu, H.; Zhang, H.; Xu, Y.; Laššáková, S.; Korabečná, M.; Neužil, P. PCR past, present and future. Biotechniques 2020, 69, 317-325. [CrossRef] [PubMed]

5. Tahamtan, A.; Ardebili, A. Real-time RT-PCR in COVID-19 detection: Issues affecting the results. Expert Rev. Mol. Diagn. 2020, 20, 453-454. [CrossRef]

6. Galluzzi, L.; Ceccarelli, M.; Diotallevi, A.; Menotta, M.; Magnani, M. Real-time PCR applications for diagnosis of leishmaniasis Parasites Vectors 2018, 11, 273. [CrossRef]

7. Zhu, H.; Zhang, H.; Ni, S.; Korabečná, M.; Yobas, L.; Neuzil, P. The vision of point-of-care PCR tests for the COVID-19 pandemic and beyond. TrAC-Trends Anal. Chem. 2020, 130, 115984. [CrossRef]

8. Wong, G.; Wong, I.; Chan, K.; Hsieh, Y.; Wong, S. A rapid and low-cost PCR thermal cycler for low resource settings. PLoS ONE 2015, 10, e0131701. [CrossRef]

9. Thiele, D. Polymerase chain reaction (PCR): Principle and applications. Immun. Infekt. 1991, 19, 138-142.

10. He, Y.H.; Ruan, G.J.; Hao, H.; Xue, F.; Ma, Y.K.; Zhu, S.N.; Zheng, B. Real-time PCR for the rapid detection of vanA, vanB and vanM genes. J. Microbiol. Immunol. Infect. 2020, 53, 746-750. [CrossRef]

11. Mulberry, G.; White, K.A.; Vaidya, M.; Sugaya, K.; Kim, B.N. 3D printing and milling a real-time PCR device for infectious disease diagnostics. PLoS ONE 2017, 12, e0179133. [CrossRef] [PubMed]

12. Sun, K.; Matsuo, S.; Misawa, H. A heater-integrated transparent microchannel chip for continuous-flow PCR. In Proceedings of the 2003 Nanotechnology Conference and Trade Show-Nanotech, San Francisco, CA, USA, 23-28 February 2003; Volume 1, pp. 86-89.

13. Li, Z.; Zhao, Y.; Zhang, D.; Zhuang, S.; Yamaguchi, Y. The development of a portable buoyancy-driven PCR system and its evaluation by capillary electrophoresis. Sens. Actuators B Chem. 2016, 230, 779-784. [CrossRef]

14. Roche, P.J.R.; Najih, M.; Lee, S.S.; Beitel, L.K.; Carnevale, M.L.; Paliouras, M.; Kirk, A.G.; Trifiro, M.A. Real time plasmonic qPCR: How fast is ultra-fast? 30 cycles in 54 seconds. Analyst 2017, 142, 1746-1755. [CrossRef] [PubMed]

15. Ahrberg, C.D.; Choi, J.W.; Lee, J.M.; Lee, K.G.; Lee, S.J.; Manz, A.; Chung, B.G. Plasmonic heating-based portable digital PCR system. Lab Chip 2020, 20, 3560-3568. [CrossRef]

16. Lim, J.; Jeong, S.; Kim, M.; Lee, J.H. Battery-operated portable PCR system with enhanced stability of Pt RTD. PLoS ONE 2018, 14, e0218571. [CrossRef]

17. Koo, C.; Malapi-Wight, M.; Kim, H.S.; Cifci, O.S.; Vaughn-Diaz, V.L.; Ma, B.; Kim, S.; Abdel-Raziq, H.; Ong, K.; Jo, Y.K.; et al Development of a real-time microchip PCR system for portable plant disease diagnosis. PLoS ONE 2013, 8, e82704. [CrossRef]

18. Veltkamp, H.W.; Monteiro, F.A.; Sanders, R.; Wiegerink, R.; Lötters, J. Disposable DNA amplification chips with integrated low-cost heaters. Micromachines 2020, 11, 238. [CrossRef]

19. Kaprou, G.D.; Papadopoulos, V.; Papageorgiou, D.P.; Kefala, I.; Papadakis, G.; Gizeli, E.; Chatzandroulis, S.; Kokkoris, G.; Tserepi, A. Ultrafast, low-power, PCB manufacturable, continuous-flow microdevice for DNA amplification. Anal. Bioanal. Chem. 2019, 411, 5297-5307. [CrossRef]

20. Kaprou, G.D.; Papadopoulos, V.; Loukas, C.-M.; Kokkoris, G.; Tserepi, A. Towards PCB-based miniaturized thermocyclers for DNA amplification. Micromachines 2020, 11, 258. [CrossRef] 
21. Gou, T.; Hu, J.; Wu, W.; Ding, X.; Zhou, S.; Fang, W.; Mu, Y. Smartphone-based mobile digital PCR device for DNA quantitative analysis with high accuracy. Biosens. Bioelectron. 2018, 120, 144-152. [CrossRef]

22. Sreejith, K.R.; Gorgannezhad, L.; Jin, J.; Ooi, C.H.; Takei, T.; Hayase, G.; Stratton, H.; Lamb, K.; Shiddiky, M.; Dao, D.V.; et al. Coreshell beads made by composite liquid marble technology as a versatile microreactor for polymerase chain reaction. Micromachines 2020, 11, 242. [CrossRef] [PubMed]

23. Mendoza-Gallegos, R.A.; Rios, A.; Garcia-Cordero, J.L. An affordable and portable thermocycler for real-time PCR made of 3D-printed parts and off-the-shelf electronics. Anal. Chem. 2018, 90, 5563-5568. [CrossRef] [PubMed]

24. Kim, Y.J.; Lim, J.H.; Lee, J.M.; Choi, J.W.; Choi, H.W.; Seo, W.H.; Lee, K.G.; Lee, S.J.; Chung, B.G. CuS/rGO-PEG nanocomposites for photothermal bonding of PMMA-based plastic lab-on-a-chip. Nanomaterials 2021, 11, 176. [CrossRef] [PubMed]

25. Folch, A. Introduction to BioMEMS; CRC Press: Boca Raton, FL, USA, 2012; 528p, ISBN 978143-9818398.

26. Zhang, C.; Xing, D. Miniaturized PCR chips for nucleic acid amplification and analysis: Latest advances and future trends. Nucleic Acids Res. 2007, 35, 4223-4237. [CrossRef] [PubMed]

27. Marcinkevicius, A.; Juodkazis, S.; Watanabe, M.; Miwa, M.; Matsuo, S.; Misawa, H.; Nishii, J. Femtosecond laser-assisted three-dimensional microfabrication in silica. Opt. Lett. 2001, 26, 277-279. [CrossRef] [PubMed]

28. Sugioka, K.; Cheng, Y. Ultrafast lasers-reliable tools for advanced materials processing. Light Sci. Appl. 2014, 3, e149. [CrossRef]

29. Gottmann, J.; Hermans, M.; Repiev, N.; Ortmann, J. Selective laser-induced etching of 3D precision quartz glass components for microfluidic applications-up-scaling of complexity and speed. Micromachines 2017, 8, 110. [CrossRef]

30. Kim, S.; Kim, J.; Joung, Y.H.; Ahn, S.; Choi, J.; Koo, C. Optimization of selective laser-induced etching (SLE) for fabrication of 3D glass microfluidic device with multi-layer micro channels. Micro Nano Syst. Lett. 2019, 7, 15. [CrossRef]

31. Kim, S.; Kim, J.; Joung, Y.H.; Ahn, S.; Park, C.; Choi, J.; Koo, C. Monolithic 3D micromixer with an impeller for glass microfluidic systems. Lab Chip 2020, 20, 4474-4485. [CrossRef]

32. Dinca, M.P.; Gheorghe, M.; Galvin, P. Design of a PID controller for a PCR micro reactor. IEEE Trans. Educ. 2009, 52, 116-125. [CrossRef]

33. Zhu, G.; Qiao, M. Nucleic acid amplification by a transparent graphene Visual-PCR chip and a disposable thermocycler. bioRxiv 2019, 1-7. [CrossRef] 